\title{
Characterisation of morbilliviruses isolated from Lake Baikal seals (Phoca sibirica)
}

\author{
L.V. Mamaev ${ }^{\text {a }}$, N.N. Denikina ${ }^{\text {a }}$, S.I. Belikov ${ }^{a}$, V.E. Volchkov ${ }^{b}$, \\ I.K.G. Visser ${ }^{\text {c,d }}$, M. Fleming ${ }^{\text {e }}$, C. Kai ${ }^{\text {f }}$, T.C. Harder ${ }^{\mathrm{g}}$, B. Liess ${ }^{\mathrm{g}}$, \\ A.D.M.E. Osterhaus ${ }^{\mathrm{c}, \mathrm{d}}$, T. Barrett ${ }^{\text {e.* }}$ \\ a The Limnological Institute, Ulan-Batorskaya 3, Irkutsk 33, Russian Federation \\ ' All Union Research Institute of Molecular Biology, Novosibirsk, Russia \\ ' Seal Rehabilitation and Research Centre, Hoofdstraat 94 A, 9968 AG Pieterburen, Netherlands \\ ${ }^{d}$ Department of Virology, Erasmus University of Rotterdam, P.O. Box 1738, 3000 DR Rotterdam, Netherlands \\ ${ }^{\mathrm{e}}$ Institute for Animal Health, Pirbright Laboratory, Pirbright, Surrey GU24 ONF, UK \\ ${ }^{\mathrm{f}}$ Department of Veterinary Microbiology, Faculty of Agriculture, University of Tokyo, III Yayoi, Bunkyo-ku. \\ Tokyo 113, Japan \\ Institute for Virology, Hannover Veterinary School, D-3000 Hannover 71, Germany
}

Accepted 4 January 1994

\begin{abstract}
Sequence analysis of the haemagglutinin protein (H) gene of the morbillivirus (PDV-2) isolated from a Siberian seal (Phoca sibirica) during the 1987/1988 epizootic in Lake Baikal revealed that it was most closely related to two recent isolates of canine distemper virus (CDV) from Germany and different from CDV vaccines currently in use in that region. The virus continued to circulate in seals in Lake Baikal after the 1987/1988 epizootic since sera collected from culled seals in the spring of 1992 were positive in morbillivirus ELISA tests, reacting most strongly with the CDV antigen.
\end{abstract}

Keywords: Morbillivirus; Lake Baikal seals; PCR; Haemagglutinin protein gene sequence

\section{Introduction}

The Morbilliviruses constitute an antigenically related genus within the Paramyxoviridae. In addition to canine distemper (CDV) which infects Canidae and Mustelidae and other carnivores (see Appel, 1987; Appel and Summers, 1995), the genus also includes measles virus (MV) which infects humans and other primates, rinderpest virus (RPV) which infects

\footnotetext{
${ }^{*}$ Corresponding author.
} 
cattle and other large ruminants, and peste des petits ruminants virus (PPRV) which infects sheep, goats and other small ruminants. The virus epizootic which occurred in seals in Northern Europe during the summer and autumn of 1988 was caused by a morbillivirus closely related to, but distinct from, CDV (Osterhaus and Vedder, 1988; Osterhaus et al., 1988; Mahy et al., 1988; Haas et al., 1991). A similar disease was seen in seals in Lake Baikal, Siberia, in December 1987, sometime earlier than the European epizootic (Grachev et al., 1989; Likhoshway et al., 1989; Osterhaus et al., 1989a, b; Titenko et al., 1990). There was no obvious epidemiological link between the outbreak in marine seals in Europe and that in freshwater seals in Lake Baikal several thousand kilometers distant. Subsequent monoclonal antibody and RT/PCR studies established that the European and Siberian seal isolates were quite different from each other and that the Siberian isolate is very similar to CDV (Osterhaus et al., 1989a; Visser et al., 1990; Barrett et al., 1992). The virus isolated from European seals is referred to as 'phocid distemper virus-1 (PDV-1)' and that isolated from Siberian seals as 'phocid distemper virus-2 (PDV-2)' (Visser et al., 1990).

$\mathrm{CDV}$ is known to infect a wide range of carnivore species and, since the live attenuated vaccines currently in use are not attenuated for wildlife species (Carpenter et al., 1976), it was possible that the infection in Baikal seals was caused by a vaccine strain of the virus widely used in domestic dogs and on mink farms in Siberia. In this paper we provide evidence, based on sequence data derived from the haemagglutinin protein $(\mathrm{H})$ gene, that a wild-type virus was responsible for the epizootic and serological evidence that the virus continued to circulate in Baikal seals after 1988.

\section{Materials and methods}

\subsection{Cells and viruses}

The following CDV virus isolates were studied: two recent German field viruses isolated from a dog and a ferret (Harder et al., 1993) and the virus (PDV-2) isolated from a Siberian seal during the epizootic in 1988 (Visser et al., 1990). All viruses were grown on Vero cells and RNA was prepared from the infected cells when extensive cpe was evident using the method described by Chomczynski and Sacchi (1987).

\subsection{DNA cloning}

The cDNA synthesis and amplification reactions were carried out on total RNA derived from tissue culture grown virus as previously described (Haas et al., 1991). The CDVspecific RNA was amplified by PCR using a primer set based on the first and last 20 nucleotides of the CDV H gene sequence published by (Curran ct al., 1991). The PCRderived DNA of the expected size was purified on low melting point agarose and cloned into the pT7 Blue PCR vector as described by the suppliers (Applied Biosystems, U.K. Ltd).

\subsection{Sequence analysis}

The resulting recombinant plasmids carrying CDV $\mathrm{H}$ gene inserts were sequenced using the M13 universal forward and reverse primers as described by Murphy and Kavanagh 
(1988) and by direct sequencing of the PCR product using labelled primers (Murray, 1989).

\subsection{ELISA}

The antigen used to coat the 96-well microtitre plates (Nunc Maxisorp, Denmark) was prepared from infected vero cells exhibiting extensive CPE using sucrose density gradient purification (Barrett et al., 1989). The antigen was diluted to a concentration of $10 \mu \mathrm{g} / \mathrm{ml}$ in phosphate-buffered saline (PBS; $135 \mathrm{mM} \mathrm{NaCl}, 26 \mathrm{mM} \mathrm{KCl}, 3 \mathrm{mM} \mathrm{CaCl}, 5 \mathrm{mM} \mathrm{MgCl}_{2}$, $70 \mathrm{mM} \mathrm{NaHPO}_{4}, \mathrm{KH}_{2} \mathrm{PO}_{4}, \mathrm{pH} 7.4$ ), and incubated for one hour at $37^{\circ} \mathrm{C}$. The plates were washed with PBS and incubated for one hour at $37^{\circ} \mathrm{C}$ with seal sera diluted in blocking buffer (PBS containing $0.1 \%$ Tween 20 and 3\% bovine serum albumin). After further washing horseradish-peroxidase conjugated protein A (Flow laboratories) was used as the second antibody diluted in blocking buffer and incubated as before. After a final wash substrate was added (o-phenylenediamine dihydrochloride, Sigma) and optical density taken at $492 \mathrm{~nm}$. A positive response was deemed to be one that was greater than twice the background of the negative control serum.

\section{Results}

\subsection{Haemagglutinin gene sequences}

At the nucleotide sequence level, PDV-2 was approximately $95 \%$ identical to the dog and ferret isolates but only $92 \%$ to the Onderstepoort vaccine. The $H$ sequences of the two vaccine strains of CDV (Onderstepoort and Convac) available on the database are $99.9 \%$ identical to each other. The nucleotide sequence data have been submitted to the EMBL database (access numbers: PDV-2: X84998; Ferret virus: X84999; Dog virus: X85000). The sequences of the various CDV isolates were subjected to pairwise sequence comparisons using the PHYLIP DNADIST program (Felsenstein, 1989). The Siberian virus PDV-2 was found to be more closely related to the two German field isolates than to the Onderstepoort vaccine when compared using either the $\mathrm{KITCH}$ or FITCH phylogenetic programs (see Fig. 1, panels a and b). All CDV sequences were quite distinct from PDV-1 with an identity of approximately $70 \%$.

The deduced amino acid sequences are presented in Fig. 2, aligned with the published CDV Onderstepoort vaccine strain. There were many scattered single amino acid changes when all proteins were compared but no clusers of amino acid changes which would indicate a site in the protein which was subject to antigenic pressure. Again the percentage identity of PDV-2 compared to the German isolates was approximately $95 \%$ but was only $89 \%$ identical to the vaccine strain. When conservative amino acid substitutions were taken into account the figures rose to $97 \%$ and $94 \%$, respectively.

\subsection{Serology}

Serum samples were collected from seals of various ages, including young pups, during the annual cull in May 1992. The details of the seals sampled and the anti-CDV neutralising 
A

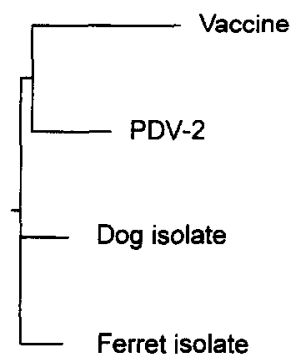

B

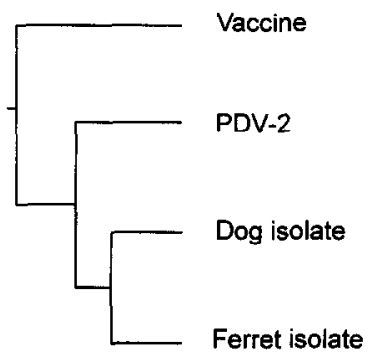

Fig. 1. Phylogenetic relationships between PDV-2 and the other CDV isolates. Trees were derived using the PHYLIP programmes (Felsenstein, 1989). Panel A: KITSCH analysis; panel B: FITCH analysis.

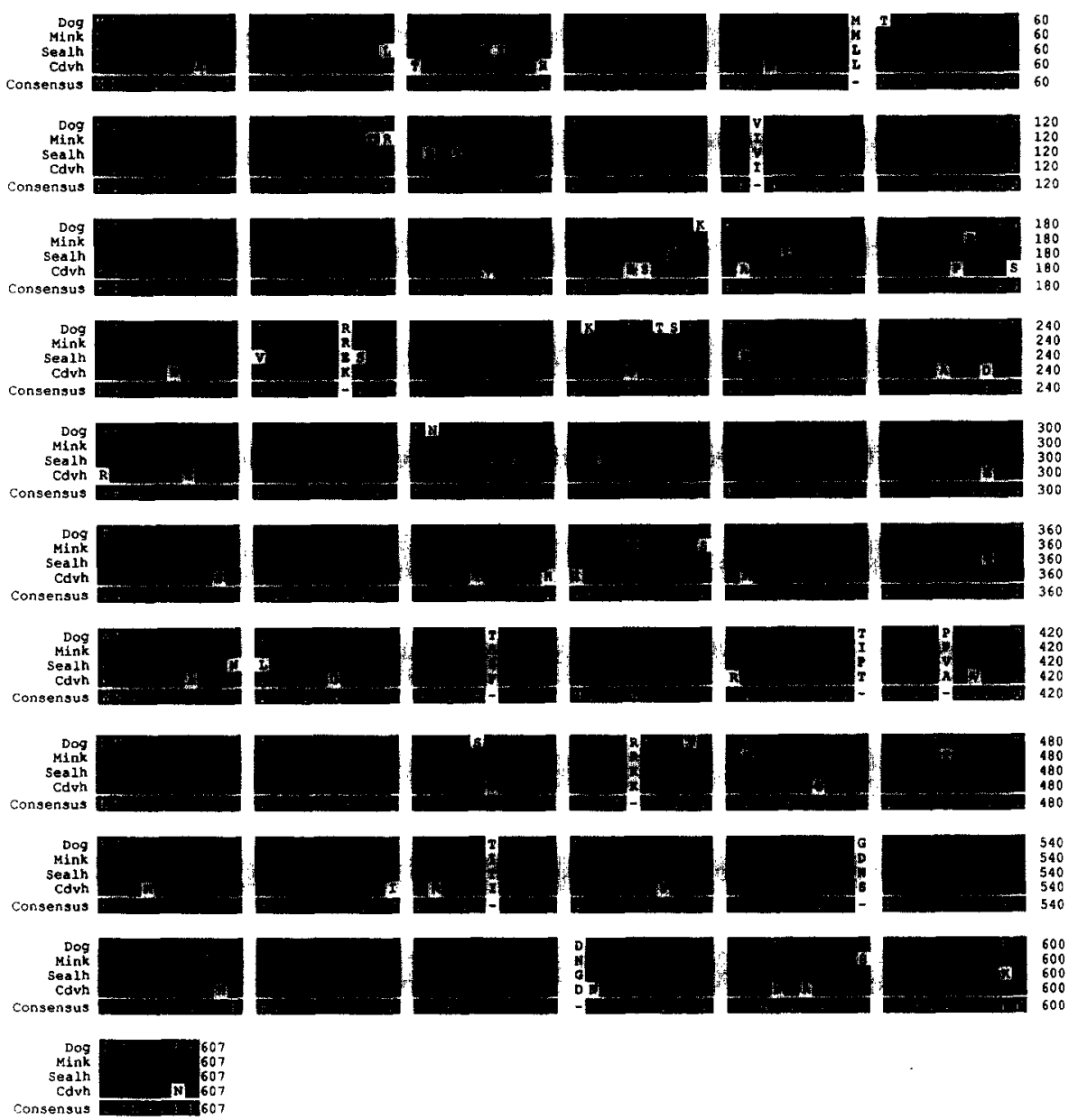

Fig. 2. Alignment of the amino acid sequence of PDV-2 with the different CDV isolates. Identical amino acids are shown in white on black while conservative and non-conservative substitutions are shown in black on grey or white, respectively. 
titres are presented in Table 1. Many of these sera showed significant neutralising titres against CDV. Since virus neutralisation can sometimes be due to other inhibitory factors in the serum, it was decided to confirm the presence of morbillivirus-specific antibodies using CDV, RPV and PPRV antigens in ELISAs. Of the fourty four Baikal seal sera tested in direct ELISA twelve showed some response with an optical density (OD) measurement twice above a negative referance sera and greater than $0.5 \mathrm{OD}^{495}$ to $\mathrm{CDV}$. A number of these sera were also found to respond when tested against RPV and PPR antigen (Fig. 3). While there was no general correlation between virus neutralisation (VN) titres and positivity in the ELISA, six sera ( $\mathrm{J} 6, \mathrm{~J} 8, \mathrm{~J} 15, \mathrm{~J} 30, \mathrm{~J} 36, \mathrm{~J} 43$ ) with high VN titres were strongly cross reactive to all the morbilliviruses tested and titrated down to $>160$ with the least cross-reactive antigen. The other strong positives, except J44, titrated down to 1:40 or greater with the RPV antigen. The age and weight of the seals bore no relationship to the presence of CDV specific antibodies.

During the initial epizootics in 1987/1988 similar ELISAs showed distinct differences in reactivity with sera from European and Siberian seals, confirming the non-identity of the two morbilliviruses (Barrett et al., 1992). The PDV-1 sera from Europe consistently reacted more strongly with rinderpest virus (RPV) and peste des petits ruminants virus (PPRV) antigens, while sera from Baikal seals always reacted most strongly with CDV antigen. For comparison positive and negative sera (PI-P3) from the European 1988 epizootic were also included and these reacted more strongly with RRPV and RPV as previously found (Fig. 3).

\section{Discussion}

The sequence studies described here clearly show that the Siberian morbillivirus isolate (PDV-2) most closely resembles recent European isolates of CDV from dog and ferret. The variation in sequence from the vaccine strains (Onderstepoort and Convac) is probably due changes in the virus since the isolation of the vaccine strains in the 1950s, while the vaccines have remained stable because they have been continuously passaged in tissue culture. Adaptation to growth in tissue culture and embryonated eggs to produce the attenuated vaccine is unlikely to have changed the sequence to any great extent since, in the case of the rinderpest vaccine, five of the six genes so far compared are $>99 \%$ identical to the virulent parent virus which was originally isolated in 1911 (Baron et al., 1993; Baron et al., 1994; Baron and Barrett, 1995). Similarly in the case of vesicular stomatitis virus, the nucleotide sequence remains constant when grown for many passages at low multiplicity in tissue culture cells (Holland et al., 1979). In contrast, sequence variation is evident in field isolates of many viruses: MV isolates from different geographical areas can be distinguished (Taylor et al., 1990) and the same is true for RPV isolates (Chamberlain et al., 1994).

CDV is known to infect a wide variety of carnivore species and its effect in wildlife populations can be devastating (Appel, 1987; Carpenter et al., 1976). However, until the identification of phocid distemper virus (PDV-1) as the cause of the seal deaths in Northern Europe in 1988, no morbillivirus had been isolated from an aquatic mammal. It was possible, therefore, that either wild type CDV or a vaccine strain of the virus used widely in domestic 
Table 1

Sample List of Baikal Seals (Phoca sibirica)

\begin{tabular}{|c|c|c|c|c|c|}
\hline Specimen No. & Collection date & Sex & Body Wt. (kg) & Body Length $(\mathrm{cm})$ & VN antibody ${ }^{a}$ \\
\hline $\mathrm{J}-1$ & 920516 & $\mathbf{F}$ & 22.7 & 92.0 & 10 \\
\hline $\mathrm{J}-2$ & 920516 & $\mathrm{~F}$ & 66.0 & 122.0 & 67 \\
\hline $\mathrm{J}-3$ & 920516 & $\mathbf{M}$ & 71.6 & 132.0 & 57 \\
\hline$J-4$ & 920516 & $F$ & 90.0 & 123.2 & 80 \\
\hline $\mathrm{J}-5$ & 920517 & $F$ & 53.0 & 118.4 & $<10$ \\
\hline $\mathrm{J}-6$ & 920518 & $\mathrm{~F}$ & 68.7 & 124.4 & 320 \\
\hline $\mathrm{J}-7$ & 920518 & $\mathrm{~F}$ & 18.9 & 79.5 & 10 \\
\hline $\mathrm{J}-8$ & 920519 & $\mathbf{M}$ & 33.1 & 95.0 & 80 \\
\hline$J-9$ & 920519 & $\mathrm{~F}$ & 80.4 & 127.7 & 34 \\
\hline $\mathrm{J}-10$ & 920519 & $\mathbf{M}$ & 20.7 & 85.6 & $<10$ \\
\hline J-11 & 920519 & $\mathrm{~F}$ & 38.2 & 109.1 & 40 \\
\hline $\mathrm{J}-12$ & 920519 & $\mathbf{M}$ & 47.8 & 113.6 & 20 \\
\hline $\mathrm{J}-13$ & 920520 & $\mathrm{~F}$ & 23.5 & 86.0 & $<10$ \\
\hline $\mathrm{J}-14$ & 920520 & $\mathbf{M}$ & 25.1 & 90.0 & 135 \\
\hline $\mathrm{J}-15$ & 920520 & $\mathbf{M}$ & 23.1 & 88.1 & 57 \\
\hline$J-16$ & 920520 & $\mathrm{~F}$ & 41.2 & 109.5 & 80 \\
\hline $\mathrm{J}-17$ & 920520 & $\mathbf{M}$ & 27.2 & 89.5 & $<10$ \\
\hline$J-18$ & 920520 & $\mathrm{~F}$ & 42.0 & 107.1 & $<10$ \\
\hline J-19 & 920520 & $\mathbf{F}$ & 30.6 & 93.1 & $<10$ \\
\hline $\mathrm{J}-20$ & 920521 & $\mathbf{M}$ & 55.1 & 120.6 & 40 \\
\hline $\mathrm{J}-21$ & 920521 & $\mathrm{~F}$ & 50.1 & 115.9 & 80 \\
\hline $\mathrm{J}-22$ & 920521 & $\mathbf{M}$ & 60.5 & 111.9 & 80 \\
\hline $\mathrm{J}-23$ & 920521 & $\mathrm{~F}$ & 60.7 & 116.8 & 20 \\
\hline $\mathrm{J}-24$ & 920521 & $F$ & 39.4 & 109.6 & 28 \\
\hline $\mathrm{J}-25$ & 920521 & $\mathrm{~F}$ & 61.6 & 115.8 & 20 \\
\hline $\mathrm{J}-26$ & 920521 & $\mathbf{M}$ & 57.9 & 120.9 & 24 \\
\hline J-27 & 920522 & $\mathbf{F}$ & 67.5 & 121.5 & 80 \\
\hline J-28 & 920522 & $\mathbf{M}$ & 55.5 & 119.2 & 34 \\
\hline J-29 & 920522 & $F$ & 47.4 & 114.0 & 28 \\
\hline J-30 & 920522 & $\mathrm{~F}$ & 34.3 & 88.5 & 905 \\
\hline $\mathbf{J}-3 \mathbf{l}$ & 920522 & $\mathrm{~F}$ & 51.8 & 115.6 & 40 \\
\hline $\mathrm{J}-32$ & 920522 & $\mathrm{~F}$ & 61.8 & 116.2 & 24 \\
\hline J-33 & 920522 & $\mathrm{~F}$ & 53.0 & 118.4 & 17 \\
\hline$J-34$ & 920523 & $\mathbf{M}$ & 72.6 & 132.7 & 40 \\
\hline J-35 & 920523 & $\mathbf{M}$ & 67.7 & 133.2 & 20 \\
\hline$J-36$ & 920525 & $F$ & 58.3 & 115.0 & 87 \\
\hline $\mathrm{J}-37$ & 920525 & $\mathbf{F}$ & 62.0 & 120.8 & $<10$ \\
\hline J-38 & 920525 & $\mathbf{M}$ & 48.9 & 120.0 & 17 \\
\hline J-39 & 920525 & $\mathrm{~F}$ & 60.3 & 115.5 & 113 \\
\hline $\mathrm{J}-40$ & 920526 & $\mathbf{M}$ & 52.5 & 118.1 & 57 \\
\hline $\mathrm{J}-41$ & 920527 & $\mathbf{M}$ & 31.0 & 88.0 & $<10$ \\
\hline $\mathrm{J}-42$ & 920527 & $\mathbf{F}$ & 22.1 & 79.7 & $<10$ \\
\hline$J-43$ & 920527 & $\mathbf{M}$ & 57.9 & 119.4 & 34 \\
\hline $\mathrm{J}-44$ & 920527 & $\mathbf{F}$ & 28.9 & 80.1 & 40 \\
\hline R-22 & 920520 & $\mathbf{M}$ & 27.8 & 101.0 & $<10$ \\
\hline
\end{tabular}

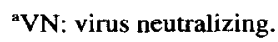




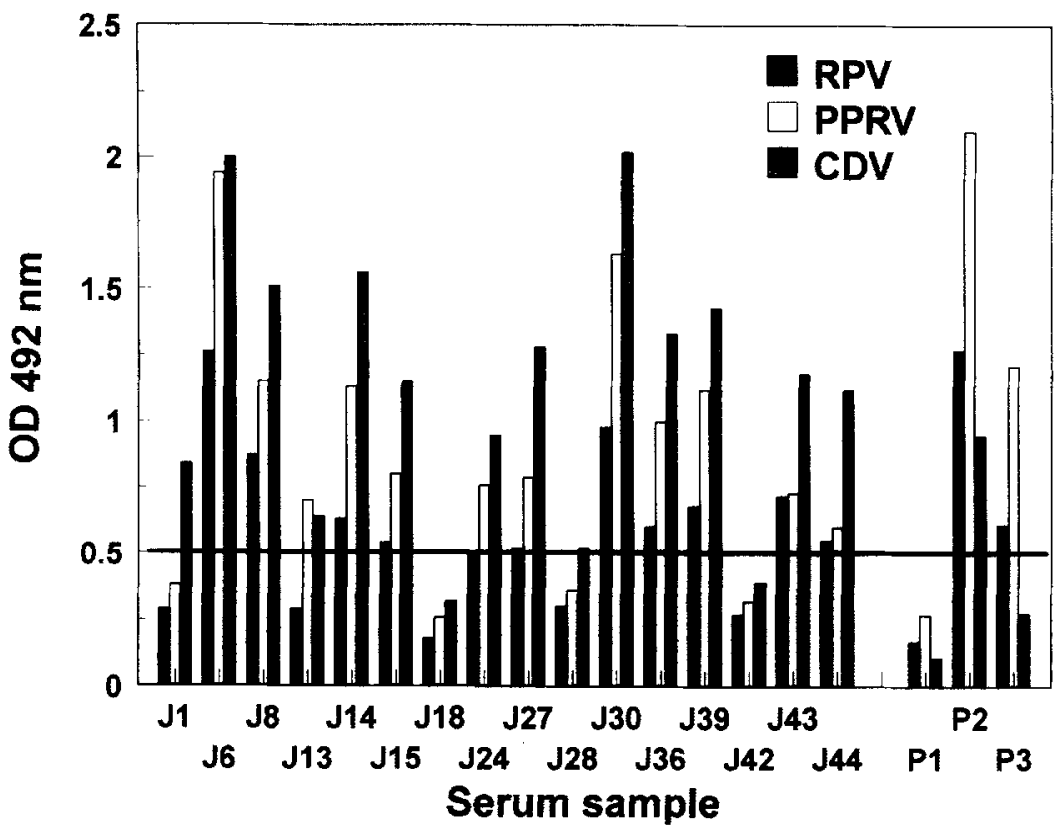

Fig. 3. ELISA results from selected sera collected from Lake Baikal seals (J1-J44) in 1992 and sera from European seals (P1-P3) collected in 1988. Three different antigens, CDV, PPRV and PRV, were used in the assays.

and farm animals (e.g. dog, mink and ferret) might have been responsible for the outbreak in the seals in Europe and Siberia. It is now firmly established that PDV-1 is a newly described virus of seals and it is probable that PDV-1 has been circulating for a considerable time in some unknown seal population, probably in the North Atlantic and Arctic Sea, before its isolation in 1988 (see Barrett et al., 1992 and Duignan et al., 1995). One likely explanation for the spread of the virus to European seals was the large-scale migration of harp seals from the Barents Sea to northern Europe in 1986-1987 (Dietz et al., 1989). Lake Baikal has no direct connection with this source of infection but it is probable that the seals there are susceptible to infection with PDV-1. The epizootic in Baikal seals was most probably caused by contact with terrestrial carnivores infected with CDV. Such outbreaks of CDV are common in wild carnivores and domestic dogs around Lake Baikal. It is highly unlikely that any of the current CDV vaccines were responsible for the epizootic in Baikal seals, however, since they are not attenuated for wild life species it is possible that the vaccines could be capable of causing disease in Siberian seals.

It appears that these viruses can readily pass between the terrestrial and aquatic environments; there is evidence that the European seal virus PDV-1 caused an infection at a mink farm near the sea in Denmark (Blixenkrone-Møller et al., 1989 and Blixenkrone-Møller et al., 1990) and CDV has been isolated from a captive seal in Canada (Lyons et al., 1993). The evidence that the virus remained in the Baikal seals after 1988 is disturbing, but it may be that the virus has always circulated in that population and was only recognised in 1988 because the molecular techniques were available to enable us to recognise it. It is necessary to study the epizootiology of these virus diseases in wild animal populations so that the pattern of interspecies infection can be understood and the risks to small endangered species carefully assessed. 


\section{Acknowledgements}

We are very grateful to Dr. Ken-ici Numachi, Tokai University, Japan and Dr. Nobuyuki Miyazaki, National Science Museum, Tokyo, Japan for providing the seal serum samples. L.V.M was the recipient of a Kapitza Fellowship from the Royal Society, London.

\section{References}

Appel, M., 1987. Canine distemper virus. In: Virus infections of vertebrates, Vol. 1: Virus infections of carnivores. Elsevier Science Publishers B.V., Amsterdam, pp. 133-159.

Appel, M.J.G. and Summers, B.A., 1995. Morbilliviruses of terrestrial carnivores. Vet. Microbiol., Special Issue: Morbilliviruses Vol. 44.

Baron, M.D., Shaila., M.S. and Barrett T., 1993. Cloning and sequence analysis of the phosphoprotein gene of rinderpest virus. J. Gen. Virol. 74: 299-304.

Baron, M.D. and Barrett, T., 1995. The sequence of the $\mathrm{N}$ amd $\mathrm{L}$ genes of rinderpest virus, and the $5^{\prime}$ and $3^{\prime}$ extragenic sequences: the completion of the genome sequence of the virus. Vet. Microbiol., Special Issue: Morbilliviruses Vol. 44.

Baron, M.D., Goatley, L. and Barrett, T., 1994. Cloning and sequence analysis of the matrix protein (M) gene of rinderpest virus: evidence for another bovine morbillivirus. Virology, 200: 121-129.

Barrett, T., Belsham, G.J., Subbarao, S.M. and Evans, S.A., 1989. Immunisation with a vaccinia recombinant expressing the $F$ protein protects rabbits from challenge with a lethal dose of rinderpest virus. Virology, 170: 11-18.

Barrett, T., Crowther, J., Osterhaus, A.D.M.E., Subbarao, S.M., Groen, J., Haas, L., Mamaev, L.V., Titenko, A.M., Grachev, M.A., Visser, I.K.G. and Bostock, C.J., 1992. Molecular and serological studies on the recent seal virus epizootics in Europe and Siberia. Science of the Total Environment, 115: 117-132.

Blixenkrone-Møller, M., Svansson, V., Have, P., Botner, A. and Nielsen, J., 1989. Infection studies in mink with seal-derived morbillivirus. Arch. Virol., 106: 165-170.

Blixenkrone-Møller, M., Svansson, V., Örvell, C. and Have, P., 1990. Phocid distemper virus - a threat to terrestial mammals? Vet. Rec., 127: 263-264.

Carpenter, J.W., Appel, M.J., Erickson, R.C. and Novilla, N., 1976. Fatal vaccine-induced canine distemper virus infection in black-footed ferrets. J. Amer. Vet. Med. Assoc., 169: 961-964.

Chamberlain, R.W., Wamwayi, H.M., Hockley, E., Shaila, M.S., Goatley, L., Knowles, N.J. and Barrett, T., 1994. Evidence for different lineages of rinderpest virus reflecting their geographic isolation. J. Gen. Virol., 74: 2775-2780.

Chomczynski, P. and Sacchi, N., 1987. Single-step method of RNA isolation by guanidinium thiocyanate-phenolchloroform extraction. Analytical Biochemistry, 162: 156-159.

Curran, M.D., Clarke, D.K. and Rima, B.K., 1991. The nucleotide sequence of the gene encoding the attachment protein $\mathrm{H}$ of canine distemper virus. J. Gen. Virol., 72: 443-447.

Dietz, R., Ansen, C.T., Have, P., Heide-Jørgensen, M.-P., 1989. Clue to seal epizootic? Nature, 338: 627.

Duignan, P.J., House, C., Geraci, J.R., Duffy, N., Rima, B.K., Walsh, M.T., Early, G., St. Aubin, D.J., Sadovc, S., Koopman, H. and Rhinehart, H., 1995. Morbillivirus infection in cetaceans of the western Atlantic. Vet. Microbiol, Special Issue: Morbilliviruses Vol. 44.

Felsenstein, J., 1989. Phylip 3.2 Manual. University of California, Herbarium, Berkley, California.

Grachev, M.A., Kumarev, V.P., Mamaev, L.V., Zorin, V.L., Baranova, L.V., Denikina, N.N., Belikov, S.I., Petrov, S.I., Petrov, E.A., Kolesnik, V.S., Kolesnik, R.S., Dorofeev, V.M., Beim, A.M., Kudelin, V.N., Magieva, F.G. and Sidorov, V.N., 1989. Distemper virus in Baikal seals. Nature, 338: 209.

Haas, L., Subbarao, S.M., Harder, T., Liess, B. and Barrett, T., 1991. Detection of phocid distemper virus RNA in seal tissues using slot hybridisation and the polymerase chain reaction amplification assay: genetic evidence that the virus is distinct from canine distemper virus. J. Gen. Virol., 74: 825-832.

Harder, T.C., Klusmeyer, K., Frey., H.-R., Örvell, C. and Liess, B., 1993. Intertypic differentiation and detection of intratypic variants among canine and phocid morbillivirus isolates by kinetic neutralisation using a novel immunoplague assay. J. Virol. Methods, 41: 77-92. 
Holland, J.J., Grabau, E.A., Jones, C.L. and Semler, B., 1979. Evolution of multiple genome mutations during long-term persistent infection by vesicular stomatitis virus. Cell, 16: 495-504.

Likhoshway, Ye.V., Grachev, M.A., Kumarev, V.P., Solodun, Yu.V., Goldberg, O.A., Belykh, O.I., Nagieva. F.G., Nikulina, V.G. and Kolesnik, B.S., 1989. Nature, 339: 266.

Lyons, C., Welsh, M.J., Thorsen, J., Ronald, K. and Rima, B.K., 1993. Canine distemper virus isolated from a captive seal. Vet. Rec., 132: 487-488.

Mahy, B.W.J., Barrett, T., Evans, S.. Anderson, E.C. and Bostock, C.J., 1988. Charactisation of a seal morbillivirus. Nature, 336: 115.

Murphy, G. and Kavanagh, T., 1988. Speeding-up the sequencing of double-stranded DNA. Nucl. Acids Res., 16: 5198.

Murray, V., 1989. Improved double stranded DNA sequencing using linear polymerase chain reaction. Nucl. Acids Res., 17: 8889.

Osterhaus, A.D.M.E., Groen, J., Vries, P. De., Uytdehaag, G.C.M., Klingeborn, B. and Zarnke, R., 1988. Canine distemper virus in seals. Nature, 335: 403-404.

Osterhaus, A.D.M.E. and Vedder, E.J., 1988. Identification of virus causing recent seal deaths. Nature, 335: 20.

Osterhaus, A.D.M.E., Broeders, H.W.J., Groen, J., Uytdehaag, F.G.C.M., Visser, I.K.G., Bildt, M.W.G., Van De Örvell, C., Kumarev, V.P. and Zorin, V.L., 1989a. Different morbilliviruses in European and Siberian seals. Vet. Rec., 125: 647-648.

Osterhaus, A.D.M.E., Groen, J., Uytdehaag, F.G.C.M., Visser, I.K.G., Bildt, M.W.G.V.D., Bergman, A. and Klingeborn, B., 1989b. Distemper virus in Baikal seals. Nature, 338: 210.

Taylor, M.J., Godfrey, E.A., Rima, B.K., Wild, T.F., Baczko, K. and ter Meulen, V., 1990. Identification of several different lineages of measles virus. J. Gen. Virol., 72: 83-88.

Titenko, A.M., Borisova, T.I., Zorin, V.L., Chipanina, V.M., Kolesnick, V.S., Kolesnick, R.S., Ishbaeva, R.I. Kapustin, Yu.M., Grachev, M.A., Golubinskii, E.P., Beim, A.M., Kudelin, V.N. and Kumarev, V.P., 1990. Isolation of morbillivirus from Baikal seal Phoca Sibirica and its preliminary characterisation. Vorp Virus., 35 (6): 502-504.

Visser, I.K.G., Kumarev, V.P., Örvell, C., Vries, P. De., Broeders, H.W.J., Bildt, M.W.G. Van De, Groen, J. and Teppema, J.S., 1990. Comparison of two morbilliviruses isolated from seals during outbreaks of distemper in North West Europe and Siberia. Arch. Virol., 111: 149-164. 